\begin{tabular}{|c|l|}
\hline Title & Systematic position of Trichadenotecnum enderleini (Roesler) (Psocodea: "Psocoptera": Psocidae) \\
\hline Author(s) & Yoshizawa, Kazunori; Smithers, Courtenay N. \\
\hline Citation & $\begin{array}{l}\text { Records of the Australian Museum, 58(3), 411-415 } \\
\text { https://doi.org/40.3853/.0067-1975.58.2006.1467 }\end{array}$ \\
\hline Issue Date & 2006-11-29 \\
\hline Doc URL & http://hdl.handle.net/2115/47521 \\
\hline Type & article \\
\hline File Information & RofAM58_2006_411.pdf \\
\hline
\end{tabular}

Instructions for use 


\title{
Systematic Position of Trichadenotecnum enderleini (Roesler) (Psocodea: "Psocoptera": Psocidae)
}

\author{
KAZUnORI YOSHIZAWA ${ }^{1 *}$ AND COURTENAY N. SMITHERS ${ }^{2}$ \\ ${ }^{1}$ Systematic Entomology, Graduate School of Agriculture, \\ Hokkaido University, Sapporo 060-8589, Japan \\ psocid@res.agr.hokudai.ac.jp \\ ${ }^{2}$ Entomology Department, Australian Museum, \\ 6 College St., Sydney NSW 2010, Australia \\ smithers@sydney.net
}

\begin{abstract}
Trichadenotecnum enderleini (Roesler, 1943) is the only native species of the genus known from Australia to date. However, its exact systematic position is not firmly fixed mainly due to the lack of information on taxonomically and phylogenetically important morphological characters. In this study, T. enderleini is examined morphologically to clarify further its systematic position. The forewing markings and male terminal structures clearly show that the species lacks all apomorphies of Trichadenotecnum Enderlein, 1909 and is thus only distantly related to the genus. Therefore, T. enderleini is excluded from Trichadenotecnum. Ptycta floresensis Endang, Thornton \& New, 2002 from Indonesia is considered to be the closest relative of T. enderleini, and T. enderleini is consequently transferred to the genus Ptycta Enderlein, 1925. As a result, Australia is excluded from the distributional range of Trichadenotecnum, except for T. circularoides Badonnel, 1955 considered to be introduced.
\end{abstract}

Yoshizawa, KAZUnORI, \& COURTENAY N. SMITHERS, 2006. Systematic position of Trichadenotecnum enderleini (Roesler) (Psocodea: "Psocoptera": Psocidae). Records of the Australian Museum 58(3): 411-415.

The genus Trichadenotecnum Enderlein, 1909 ("Psocoptera": Psocidae) has long been characterized by the superficial similarities of forewing markings and venation and has included a heterogeneous assemblage of species. Although recent morphological and molecular analyses provided a clear limit of the genus as a monophyletic group (Yoshizawa, 2001, 2003, 2004), further examination of some species placed currently in the genus is required to clarify their exact systematic position. In particular, the correct systematic placement of the only endemic Australian species of the genus, T. enderleini (Roesler, 1943) (Smithers, 1996), is needed to understand more clearly the distributional range and biogeography of the genus. Morphological characters of T. enderleini have not been examined since its original description, in which only fore- and hindwing venation and coloration were illustrated; no information on genital structures has been provided.

The species was originally described as Psocus conspurcatus Enderlein, 1903. Subsequently, the species was transferred to the genus Trichadenotecnum by Enderlein (1925) based on the superficial resemblance of forewing venation and markings. The specific epithet, conspurcatus, was preoccupied by Psocus conspurcatus Rambur, 1842 and thus Roesler (1943) gave the new specific epithet, 
enderleini, to the species and placed it in the genus Psocidus s.l. Thornton (1961) noted a possibility of close affinity between the species and the genus Trichadenotecnum based on the triangular areola postica and the spotted forewing. However, he did not make a formal nomenclatural statement concerning its generic placement. The species was transferred formally to the genus Trichadenotecnum by Smithers (1967), and this taxonomic treatment has been followed subsequently (see synonymy below).

The above taxonomic acts were done without detailed morphological information on the species. Especially, placement of the species in the genus Trichadenotecnum is based on superficial similarities of the forewing venation and markings. However, such venation and markings are known in some distantly related groups (Yoshizawa, 1998). Therefore, to decide the exact taxonomic position of the species, detailed information on important taxonomic and phylogenetic characters (e.g., male terminalia) is required. In the present paper, Trichadenotecnum enderleini is examined morphologically and its systematic position is discussed.

Methods of morphological examination follow Yoshizawa (2002). All specimens examined are in the Australian Museum, Sydney.

\section{Systematics}

\section{Ptycta enderleini (Roesler) n.comb.}

Figs 1-3

Psocus conspurcatus Enderlein, 1903: 224 (type locality: Royal Botanical Gardens Sydney, NSW, Australia).-Junior homonym of Psocus conspurcatus Rambur, 1842.

Trichadenotecnum conspurcatum (Enderlein).-Enderlein, 1925: 105.

Psocus enderleini Roesler, 1943: 13 (new name for $P$. conspurcatus Enderlein).

Psocidus enderleini (Roesler).—Roesler, 1943: 13; Thornton, 1961: 2.

Trichadenotecnum enderleini (Roesler).--Smithers, 1967: 115; Smithers, 1977: 290; Smithers, 1996: 75; Lienhard \& Smithers, 2002: 464

Material examined. Australia, New SOUTH WALES: 19 , Lake Cathie, nr Port Macquarie, 12.v.1977, A.S. \& C.N. Smithers; 2 oे ơ 1 으, Trial Bay Gaol, 12.v.1977, C.N. \& A.S.

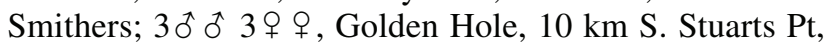
13.v.1977, C.N. \& A.S. Smithers; $20 \hat{0}$, Broadwater Nat. Park, 6.v.1978, C.N. Smithers; 1 o, Wyrrabalong Nat. Park, 27.xi.1997, L. Wilkie; 1 , , Bola Creek, Nat. Park, 6.x.1965, A.S. Smithers.

Redescription. Male. Head white in ground colour; vertical and orbital markings brown; coronal suture pale; epicranial suture bordered with narrow brown band dorsally; frons pale brown, with irregular brown spots; eye black, large, $\mathrm{IO} / \mathrm{D}=0.85$; ocelli white, ocellar field blackish brown; gena white; antennal socket bordered with narrow brown band; postclypeus with c. 10 longitudinal rows of brown spots; anteclypeus pale brown. Antenna pale brown, scape and pedicel slightly darker. Mouth parts white, tip of fourth segment of maxillary palpus blackish brown. Thorax. Prothorax brown. Mesonotum brown except median part, anterior lobe and lateral margins of lateral lobes of scutum

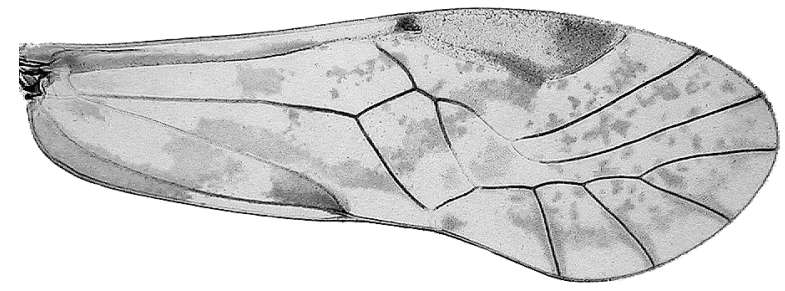

Fig. 1. Forewing of Ptycta enderleini, male.

white; scutellum brown; postnotum blackish brown. Metanotum brown except anterior lobe of scutum white. Meso- and metapleura blackish brown except membranous regions white. Legs white; mid and hind coxae brown; all femora with blackish brown marking near distal end; 2nd tarsomere and claws brown. Forewing (Fig. 1) hyaline with brown markings; distal region sparsely covered with small spots; medially with narrow brown band running from posterior corner of pterostigma through centre of discoidal cell to distal end of cell cup; basal quarter with broad band widely interrupted around vein M. Pterostigma white except distal 2/s; posterior margin brown. Anal cell brown in basal half. Veins blackish brown except along Rs fork, distal half of $\mathrm{M}$ closing discoidal cell, and $\mathrm{CuA}_{2}$ white; Rs fork acute; areola postica almost triangular. Hindwing hyaline; veins brown except R1, basal section of Rs and Rs+M paler. Abdomen white except first segment and terminalia brown. Terminalia (Fig. 2): Posteroventral region of clunium (Fig. 2A) widely membranous. Eighth sternum (Fig. 2A) without sclerite. Epiproct (Fig. 2B) with two pairs of long setae laterally; epiproct lobe weakly expanded dorsally. Paraproct (Fig. 2A) with large basal lobe dorsally and with cone-like projection posteromedial to trichobothrial field; distal process very long, strongly curved. Hypandrium (Fig. 2C) symmetrical, deeply incised at middle; posterodorsal arms bulbous, each with row of tiny denticles; posterodorsal region with two pairs of processes, external pair small, triangular, arising just below bulbous arms, internal pair large, each with broad and rounded base and pointed distal end; lateral region covered with denticles; median region with longitudinal row of long and transparent articulated spines just below incision; ventral region with two pairs of processes, external pair small, internal pair long. Phallosome (Fig. 2D,E) very long; phallobase with welldeveloped lateral process, anteroventrally rounded. Length (mm): body (B) 2.5-3.0; forewing (FW) 3.4-3.7; hindwing (HW) 2.6-2.9.

Female. Coloration and general morphology, except terminalia, almost as in male; pigmentation much paler, probably due to long alcohol preservation; eye small, IO/ $\mathrm{D}=$ 2.0. Genitalia (Fig. 3): Egg guide of subgenital plate (Fig. 3A) almost as long as wide, parallel sided, apical margin almost straight, with six thick setae and many fine setae, lateral margin also with few strong setae; body of subgenital plate V-shaped but very slightly pigmented, probably due to long alcohol preservation. Ventral valve of gonapophyses (Fig. 3B) short; dorsal valve narrow; external valve without posterior lobe, anteroexternally with thumbshaped lobe. Internal plate well sclerotized. Length: B 2.8 3.2; FW 3.8-4.0; HW 2.7-3.0.

Distribution. Australia (NSW). 


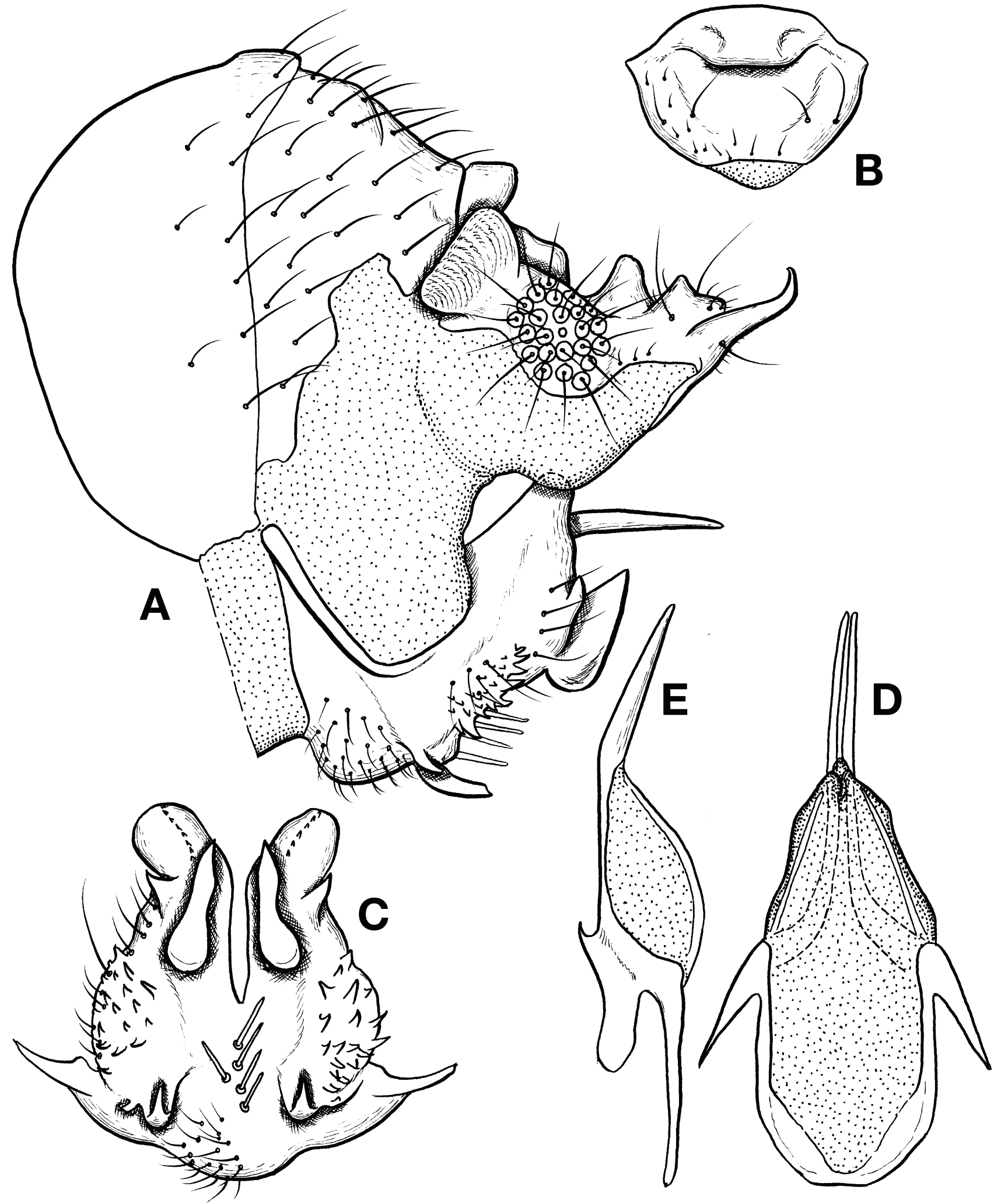

Fig. 2. Male terminal structures of Ptycta enderleini. (A) Terminalia, lateral view. $(B)$ Epiproct, dorsal view. $(C)$ Hypandrium, posterior view. $(D)$ Phallosome, ventral view. $(E)$ Ditto, lateral view. 
Remarks. Ptycta enderleini is most similar to P. floresensis Endang, Thornton \& New, 2002 in forewing markings (especially in the female), medially incised hypandrium, and apically elongated phallosome. In particular, the apically elongated phallosome is apomorphic and uniquely shared by $P$. floresensis and $P$. enderleini; this character state indicates their close affinity. Female structures of gonapophyses in P. enderleini, such as the narrow dorsal valve and lack of the posterior lobe of the external valve, are similar to $P$. verticalis Vaughan, Thornton \& New, 1991 and P. merapiensis Endang, Thornton \& New, 2002. However, $P$. enderleini can be easily distinguished from these species by the unique forewing markings and the hypandrial structures.

\section{Discussion}

We conclude that $P$. enderleini cannot be assigned to the genus Trichadenotecnum because of lack of all apomorphies supporting the monophyly of the genus (Yoshizawa, 2001, 2003). For example, the forewing of $P$. enderleini lacks the six submarginal spots and opposing spots in cell $r$ which characterize the genus Trichadenotecnum. Rather, presence of the paraproctal basal lobe in the male suggests that the species is related to the genus Copostigma Enderlein, 1903 (Smithers, 1985; Endang et al., 2002).

However, $P$. enderleini lacks an important apomorphic character of Copostigma, namely a cross vein connecting Rs and $\mathrm{M}$ in the forewing. In addition, the male genital structures in Psocidae are known to be highly variable and sometimes homoplasious (e.g., Yoshizawa, 2004; Yoshizawa $\&$ Lienhard, 2004), and the paraproctal basal lobe observed in Copostigma and P. enderleini might also possibly have evolved independently; this should be tested on the basis of molecular phylogeny. Here, we place this species in the genus Ptycta Enderlein, 1925, following the treatment by Endang et al. (2002). Judging from the morphological features, the closest relative of $P$. enderleini is considered to be P. floresensis Endang, Thornton \& New, 2002 (see remarks above). In addition, some species of Ptycta are known to possess the paraproctal basal lobe in males (e.g., Endang et al., 2002). Therefore, placement of P. enderleini under the genus Ptycta is considered to be the best solution at present. However, as mentioned by Lienhard \& Smithers (2002) and Endang et al. (2002), the genus Ptycta now includes many heterogeneous species and is thus possibly

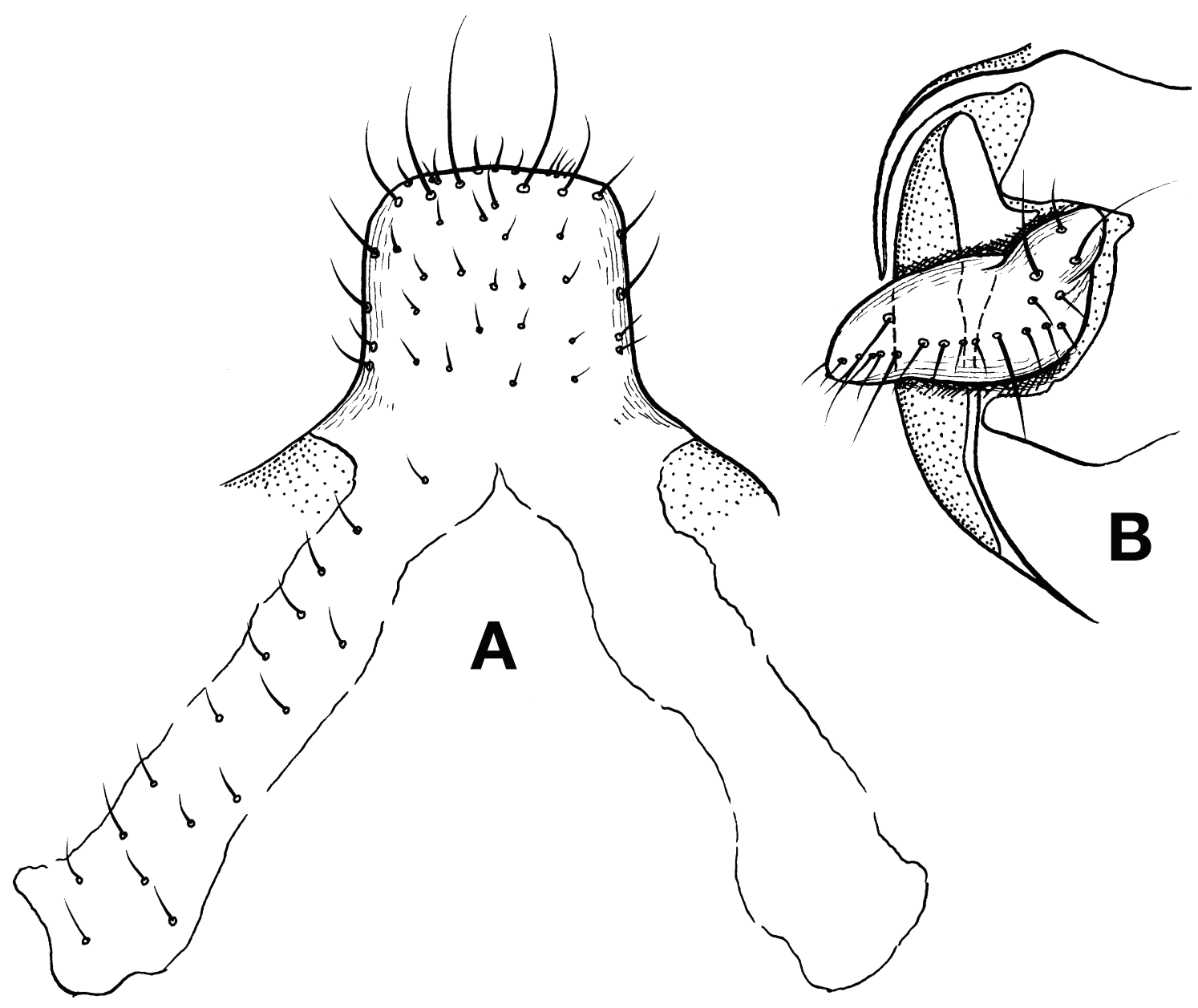

Fig. 3. Female genitalia of Ptycta enderleini. (A) Subgenital plate, ventral view, setae on right half omitted. (B) Gonapophyses, ventral view. 
polyphyletic. Therefore, its generic status and the higher systematics of the genus complex ClematostigmaCopostigma-Mecampsis-Ptycta must be revised by detailed morphological and molecular analyses based on a wide range of taxon sampling (Smithers, 1983; Lienhard \& Smithers, 2002; Endang et al., 2002).

Australia is thus excluded from the distributional range of the genus Trichadenotecnum except for T. circularoides Badonnel, 1955 which was recorded from Queensland, Australia by Yoshizawa (2004). For the following reasons, it is considered that the species is probably introduced to Australia and is not native: $(a)$ the species shows extremely broad distributional range (Mockford, 1993; Yoshizawa, 2001; Lienhard \& Smithers, 2002); (b) Australian and Japanese populations of $T$. circularoides show completely identical gene sequences (cytochrome oxidase I, NADH dehydrogenase subunit 5, 12S, $16 \mathrm{~S}$ and $18 \mathrm{~S}$ rDNA: Yoshizawa, unpublished data; those sequences of the Australian sample are available online at GenBank); (c) close relatives of the species are known only from Central and South America (Mockford, 1993; Yoshizawa, unpublished data).

ACKNOWLEDGMENTS. We thank L. Wilkie for valuable material and two anonymous referees for valuable comments.

\section{References}

Badonnel, A., 1955. Psocoptères de l'Angola. Publicacões culturais da Companhia de Diamantes de Angola 26: 1-267.

Endang, S.K., I.W.B. Thornton \& T.R. New, 2002. The Psocidae (Insecta: Psocoptera) of Java and the eastern islands of Indonesia. Invertebrate Systematics 16: 107-176.

Enderlein, G., 1903. Die Copeognathen des indo-australischen Faunengebietes. Annales historico-naturales Musei nationalis Hungarici 1: 179-344.

Enderlein, G., 1909. Neue Gattungen und Arten nordamerikanischer Copeognathen. Bulletino del Laboratorio di Zoologia generale e agrariae della R. Scuola Superiore d'Agricoltura in Portici 3: 329-339.

Enderlein, G., 1925. Beiträge zur Kenntnis der Copeognathen IX. Konowia 4: 97-108.

Lienhard, C., \& C.N. Smithers, 2002. Psocoptera. World Catalogue \& Bibliography. Instrumenta Biodiversitatis V, Muséum d'histoire naturelle, Genève, xli+1-745 pp.

Mockford, E.L., 1993. North American Psocoptera. Flora \& Fauna Handbook No. 10, Florida: Sandhill Crane Press, xviii+455 pp.
Rambur, J.P., 1842. Histoire naturelle des insectes. Névroptères. Paris, xvii+534 pp.

Roesler, R., 1943. Über einige Copeognathengenera. Stettiner Entomologische Zeitung 104: 1-14.

Smithers, C.N., 1967. A catalogue of the Psocoptera of the world. Australian Zoologist 14: 1-145.

Smithers, C.N., 1977. The Psocoptera of Muogamarra Nature Reserve. Records of the Australian Museum 31(7): 251-306.

Smithers, C.N., 1983. A reappraisal of Clematostigma Enderlein with notes on related genera (Psocoptera: Psocidae). Australian Entomological Magazine 9(5): 71-79.

Smithers, C.N., 1985. Redefinition of Copostigma Enderlein (Psocoptera: Psocidae). Australian Entomological Magazine 13(3,4): 61-62.

Smithers, C.N., 1996. Psocoptera. In Zoological catalogue of Australia. Vol. 26. Psocoptera, Phthiraptera, Thysanoptera, ed. A. Wells, pp. 1-79. Melbourne: CSIRO publishing, xiii+418 pp.

Thornton, I.W.B., 1961. The Trichadenotecnum group (Psocoptera: Psocidae) in Hong Kong, with descriptions of new species. Transactions of the Royal Entomological Society of London 112: 239-261.

Vaughan, P.J., I.W.B. Thornton \& T.R. New, 1991. Psocoptera from southern Sumatra and West Java, Indonesia: Source faunas for colonisation of the Krakatau Islands. Treubia 30: $103-164$.

Yoshizawa, K., 1998. A new genus, Atrichadenotecnum, of the tribe Psocini (Psocoptera: Psocidae) and its systematic position. Entomologica scandinavica 29: 199-209.

Yoshizawa, K., 2001. A systematic revision of Japanese Trichadenotecnum Enderlein (Psocodea: 'Psocoptera': Psocidae: Ptyctini), with redefinition and subdivision of the genus. Invertebrate Taxonomy 15: 159-204.

Yoshizawa, K., 2002. Phylogeny and higher classification of suborder Psocomorpha (Insecta: Psocodea: 'Psocoptera'). Zoological Journal of the Linnean Society 136: 371-400.

Yoshizawa, K., 2003. Two new species that are likely to represent the most basal clade of the genus Trichadenotecnum (Psocoptera: Psocidae). Entomological Science 6: 301-308.

Yoshizawa, K., 2004. Molecular phylogeny of major lineages of Trichadenotecnum and a review of diagnostic morphological characters (Psocoptera: Psocidae). Systematic Entomology 29: 383-394.

Yoshizawa, K., \& C. Lienhard, 2004. Systematics of Trichadenotecnum (Psocoptera: Psocidae) in Hong Kong. Publicaciones Especiales del Instituto de Biologia, Universidad Nacional Autonoma de Mexico 20: 121-149.

Manuscript received 15 August 2005, revised 2 December 2005 and accepted 13 January 2006.

Associate Editor: Dan J. Bickel. 
